to this cadre of tests; and as their role in immunoregulation becomes better understood, their measurement may also help in the assessment of the immune status-which may soon have to be taken into account in the design of therapy.

1 Sarcione, E. J., Cancer Research, 1967, 27, 2025.

2 Benjamin, D. C., and Weimer, H. E., Nature, 1966, 209, 1032.

3 Abelev, G. I., et al., International fournal of Cancer, 1967, 2, 551.

4 Ablin, R. J., Lancet, 1972, 2, 874.

5 Suga, S., and Tamura, Z., Cancer Research, 1972, 32, 426.

$\checkmark$ Douma, G. J., and Dalen, van A., Zeitschrift für klinische Chemie und klinische Biochemie, 1974, 12, 474 .

7 McPhedran, P., et al., Annals of Internal Medicine, 1972, 76, 439.

7 McPhedran, P., et al., Annals of Internal Medicine

8 Rimbaut, C., Bulletin du Cancer, 1973, 60, 411 . Biology and Medicine, 1972, $139,575$.

10 Glasgow, A. H., et al., New England fournal of Medicine, 1974, 291, 1263. 11 Mackay, A. M., et al., British Medical fournal, 1974, 4, 382.

\section{Influencing Governments}

As the Standing Committee of Doctors moves into a closer relationship with the E.E.C. Commission the 26 years' experience of British doctors in influencing government policy could be invaluable. Unlike most countries in the Community the profession and successive governments in the United Kingdom have long recognized the value of their contributing directly in official committees, inquiries, and advisory bodies. In fact, without this professional commitment the N.H.S. could hardly have survived.

Last weekend the Heads of Delegations of the Standing Committee of Doctors of the E.E.C. discussed the political problems of the transitional period in their regular two-day Spring meeting-including how best to influence the Commission. With the medical directives ${ }^{1}$ about to be signed it is only 18 months before they come into effect. The consequences of these directives for the free movement of doctors throughout the Nine are hard to predict but Dr. Alan Rowe, who leads the British delegation, makes his forecasts on p. 438.

After 15 years or so of shadow boxing between the Standing Committee and the European Commission about the directives their imminence caused a surprising amount of anxiety in the Committee. Despite the doctors' increasing official influence at Common Market headquarters members were not euphoric. Indeed, the old hands were playing it cool, wary of anything that emanated from official sources. Several speakers were critical that the Standing Committee's proposals for an advisory committee on the quality of doctors' training ${ }^{2}$ had not been fully accepted. A resurrected proposal for noncooperation with the Commission unless each government accepted its national delegation's recommendation for the "practising doctor" representative on the advisory committee failed again, but only because it did not command unanimous support-a prerequisite for major policy decisions. Nevertheless, Mr. Walpole Lewin, President of the Standing Committee, argued forcefully that much has indeed been achieved in getting doctors' views accepted. He is right: it would have been politically unrealistic to expect the Community's Council of Ministers (see p. 438), whose decisions stem from national government policies, to have adopted all the profession's proposals.
The Standing Committee was right, however, to be suspicious of an unexpected arrival in the medical directives: a committee made up of senior officials in public health from each government and intended to deal with difficulties during the transitional period-and after. Members thought the new committee, which might well contain no doctors, could trespass on the functions of the Standing Committee-and because of its composition the result could be only to the disadvantage of the medical profession. The committee had arisen, apparently, because of internal political difficulties in one of the Nine but its arrival did not impress the Heads of Delegations. So they decided to set up a watchdog group to keep an eye on the unwelcome newcomer and at the same time advise the Commissioners about any transitional problems.

The meeting's customary reception was on this occasion held, appropriately enough perhaps, at the Palace of Westminster, where Dr. Gerard Vaughan, M.P., and Mr. Geoffrey Rippon, M.P., were hosts at an excellent evening. This was, surprisingly, the only occasion throughout the two days when Britain's future in - or out -of the European Community was formally mentioned in a speech. Were delegates confident that the United Kingdom would stay in or were they too polite to refer to their hosts' temporary national uncertainty ?

1 British Medical fournal, 1975, 1, 466

2 British Medical fournal, 1974, 4, 604.

\section{Dental Anaesthesia: The Final Act}

"A practitioner who regularly administers general anaesthetics single-handed for conservation work is, in my view, acting inexcusably." With these words, spoken in his first address to the General Dental Council, its new president Mr. Rodney Swiss effectively puts to an end a practice that has led to too many deaths in the dental chair. ${ }^{1}$ In his speech (quoted at length at p. 453) Mr. Swiss makes it clear that the administration of a general anaesthetic and the care of an unconscious patient require the full attention of a qualified doctor or dentist, and that (except in an emergency) no dentist should attempt to act as operator and anaesthetist combined. This view, strongly urged by a Ministry of Health inquiry ${ }^{2}$ as long ago as 1967 , is one which we have pressed repeatedly, ${ }^{3}$ and it was at the heart of the long libel action brought against the B.M.F. by Mr. S. L. Drummond-Jackson. ${ }^{4}$ In his address, Mr. Swiss described the role of the G.D.C. as promoting high standards of professional conduct among dentists; and this he has certainly done by stating his position on dental anaesthesia so unequivocally.

\footnotetext{
${ }^{1}$ British Medical fournal, 1975, 1, 293.

${ }^{2}$ Ministry of Health, Dental Anaesthesia, Report of foint Subcommittee of the Standing Medical and Dental Advisory Committee on Dental Anaesthesia. London, H.M.S.O., 1967.

${ }^{3}$ British Medical fournal, 1969, 2, 525.

${ }^{4}$ British Medical fournal, 1972, 4, 313.
} 